AL-AMWAL: JURNAL EKONOMI DAN PERBANKAN SYARI'AH (2021) Vol 13: 203-214

DOI: $10.24235 / a m w a l . v \% v i \% i .7599$

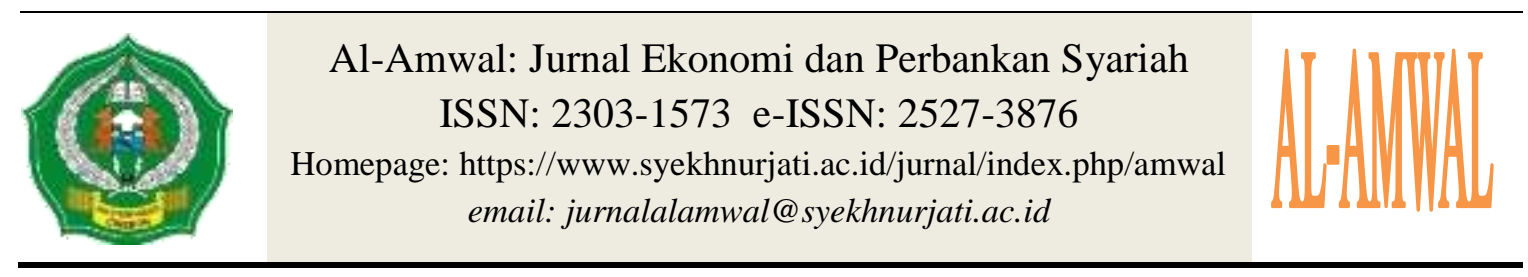

\title{
The Impact of Gross Enrollment Ratio (GER) of Tertiary Education in Indonesia on the Literacy and Inclusion Index: A Case Study Of Islamic Finance in Indonesia
}

\author{
Zulfikar Hasan \\ Department of Islamic Banking and Center for Research and Community Service at \\ STAIN Bengkalis Riau Indonesia. \\ email: zulfikarhasan61@ gmail.com \\ Saifunnajar \\ STAIN Bengkalis \\ Email : saifunnajar@gmail.com
}

\begin{abstract}
The inclusion and literacy of Islamic finance is an index that can use as a guide in assessing whether people living in a country know about Islamic finance. Multiple variables can conclude whether a nation knows Islamic banking, one of the variables that can use as guidelines are the literacy and inclusion index published by affiliated organisations such as the Financial Services Authority (OJK). The Financial Services Authority does a survey that can use as further research on the knowledge of the Indonesian people about Islamic Banking. Overall, the third National Financial Literacy Survey (SNLIK) conducted by the Financial Services Authority (OJK) this year showed that the financial literacy index reached $38.03 \%$, and the financial inclusion index 76.19\%. This figure improved related to the results of the 2016 OJK survey, correctly the financial literacy index $29.7 \%$ and the financial inclusion index $67.8 \%$. Based on regional levels, for urban financial literacy index reached $41.41 \%$ and economic inclusion of urban areas amounted to $83.60 \%$. In comparison, the literacy index and financial inclusion of rural communities were $34.53 \%$ and $68.49 \%$. The survey results also showed that based on gender literacy index and economic inclusion of men were $39.94 \%$ and $77.24 \%$, relatively higher than women at $36.13 \%$ and $75.15 \%$. OJK will use the results of the 2019 financial literacy survey to refine the national financial literacy development strategy that is more effective and targeted.
\end{abstract}

Keywords: Gross Enrollment Ratio (GER), literacy, inclusion, islamic finance, tertiary education 


\begin{abstract}
Abstrak
Inklusi dan literasi keuangan syariah merupakan indeks yang dapat digunakan sebagai pedoman dalam menilai apakah masyarakat yang tinggal di suatu negara mengetahui tentang keuangan syariah. Beberapa variabel dapat menyimpulkan apakah suatu bangsa mengenal perbankan syariah, salah satu variabel yang dapat dijadikan pedoman adalah indeks literasi dan inklusi yang diterbitkan oleh organisasi terafiliasi seperti Otoritas Jasa Keuangan (OJK). Otoritas Jasa Keuangan melakukan survei yang dapat digunakan sebagai penelitian lebih lanjut tentang pengetahuan masyarakat Indonesia tentang Perbankan Syariah. Secara keseluruhan, Survei Literasi Keuangan Nasional (SNLIK) ketiga yang dilakukan oleh Otoritas Jasa Keuangan (OJK) tahun ini menunjukkan indeks literasi keuangan mencapai 38,03\%, dan indeks inklusi keuangan 76,19\%. Angka ini membaik terkait hasil survei OJK 2016, benar indeks literasi keuangan 29,7\% dan indeks inklusi keuangan $67,8 \%$. Berdasarkan tingkat wilayah, indeks literasi keuangan perkotaan mencapai $41,41 \%$ dan inklusi ekonomi perkotaan sebesar $83,60 \%$. Sebagai perbandingan, indeks literasi dan inklusi keuangan masyarakat pedesaan adalah 34,53\% dan $68,49 \%$. Hasil survei juga menunjukkan bahwa berdasarkan indeks literasi gender dan inklusi ekonomi laki-laki adalah 39,94\% dan 77,24\%, relatif lebih tinggi dibandingkan perempuan sebesar $36,13 \%$ dan $75,15 \%$. OJK akan menggunakan hasil survei literasi keuangan 2019 untuk menyempurnakan strategi pengembangan literasi keuangan nasional yang lebih efektif dan tepat sasaran.
\end{abstract}

Kata kunci: Angka Partisipasi Kasar (APK), literasi, inklusi, keuangan syariah, pendidikan tinggi

\title{
INTRODUCTION
}

Indonesia is a country that has high economic potential; the potential that started to be noticed by the international community. Indonesia has various characteristics that put this country in a unique position to experience accelerated economic development. Moreover, in recent years there has been powerful support from the central government to control Indonesia's dependence on (raw) commodity exports while enhancing the role of manufacturing industries in the economy. Infrastructure development is additionally the primary purpose of the government, and that needs to cause a multiplier impact on the economy.

From the banking side in the last few years, the development of bank business has begun to fade. Growth in third party funds (DPK) and lending began to slow down. Even since 2013, DPK growth has been below 10\%. In 2013, DPK growth fell sharply from $15.59 \%$ to only $8.89 \%$. While the credit increase fell from $22.64 \%$ to $16.57 \%$, the slowing trend continues to this day, namely the growth of deposits and lending is still trying to return to the pattern before 2013. Even today, the extension of deposits is always challenging to penetrate double-digit numbers. On the other hand, the government, along with the monetary policy authority, has sought to encourage the performance of banking institutions by making expansionary policies.

The development of the Islamic financial industry in Indonesia advances to increase until presently. Data from the Financial Services Authority (FSA) records in 2017, the total Islamic financial assets in Indonesia relinquished Rp 992.80 trillion with the Islamic banking industry leading Rp. 375.75 trillion, sharia capital market Rp. 
522.42 trillion and Sharia IKNB Rp. 94.63 trillion. The symbolises that people increasingly believe in the existence of Islamic financial institutions, especially in the Islamic banking sector. However, the increase in Islamic financial assets is not comparable to the public's understanding of Islamic financial products and services. The latest results from the OJK National Literacy and Financial Survey in 2016 show that the Islamic financial literacy index in Indonesian society is $8.1 \%$. The research shows that the level of Islamic financial literacy in Indonesia is still low, meaning that only 8 out of 100 people understand for Islamic financial products and services.

The Financial Services Authority (OJK) has explained the opportunities and challenges of Islamic banking in Indonesia are: (1). Global conditions. (2). International standards and commitments. (3). Financial sector integration. (4). Sustainable growth. (5). Equitable development. (6). Financial stability. (7). Demography bonus. (8). Financing gaps, market potential and deepening. (9). Public literacy in Islamic financial services is still low. In addition to these opportunities and challenges, there are several strategic issues in the development of Islamic banking, including expensive funding costs community understanding and awareness is still low. Based on the 2016 National Financial Literacy and Inclusion Survey, the Islamic financial inclusion index is still shallow.

Based on data from the Financial Services Authority (OJK), the financial literacy index in 2019 reached 38.03 per cent. This figure increased compared to the same survey in 2016, which was 29.7 per cent. Indonesia also recorded an increase in the financial inclusion index from 67.8 per cent in 2016 to 76.19 per cent in 2019 . Access to financial products and services has become an essential requirement for modern society. The reason is that the availability of access allows individuals or organizations to conduct a variety of financial transactions, both productive and wasteful. Easy access to finance will enable transactions to take place quickly so that the volume of financial transactions becomes more prominent, and vice versa. At the micro-level, productive financial transactions can create employment opportunities and provide opportunities for the community to increase their income. At the macro level, the accumulation of financial transactions will contribute to a country's economic growth. Unfortunately, the condition of public access to products and financial services are not the same in all states. Communities in developed countries generally have high access, but this is not the case with residents in developing and underdeveloped countries. Differences in access cause financial inclusiveness to differ between countries. Authorities in each country are periodically working from time to time to increase the level of financial inclusion among their people. Some managed to do it well, but some others still face a variety of constraints. The Government of Indonesia also experiences this condition, so it is interesting to study the development of the level of financial inclusion compared to development indicators. 


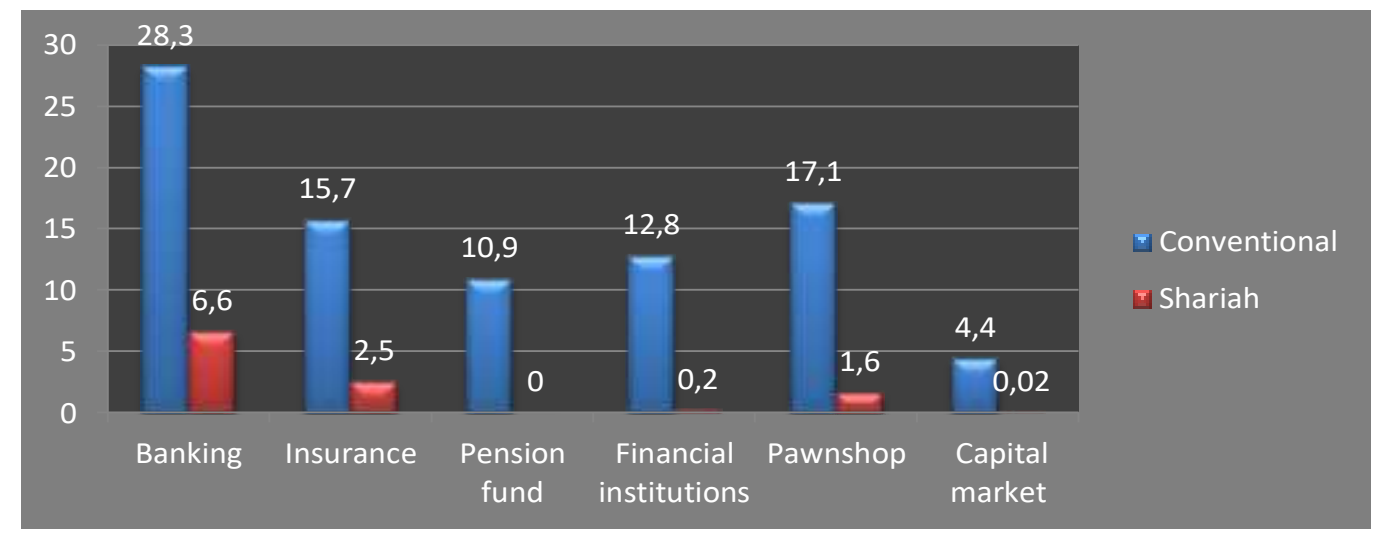

Figure 1.0: Literacy Financial Index 2016

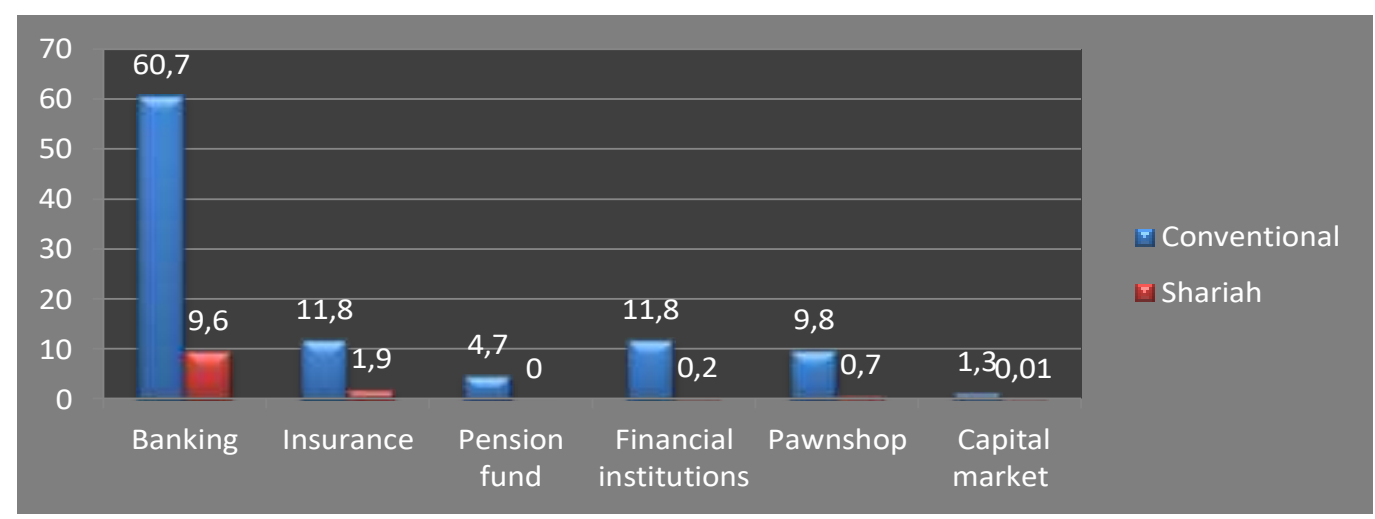

Figure 2.0: Inclusion Financial Index 2016

The latest data also reveals that there are only $36 \%$ or nearly 90 million Indonesian adults who have accounts in banks (World Bank Data, 2017). This number is far behind Malaysia, which reaches $81 \%$, China 79\%, India 53\% (Global Findex, 2017). These problems indicate that financial literacy and financial inclusion will not appear by themselves. That is because financial literacy facilitates the effective use of products and helps businesses develop skills and financial products that best suit their needs, these conditions as a condition for increasing financial inclusion. Financial inclusion is a person's ability to get access to various financial products and services that are affordable and as needed. Financial inclusion can make changes in the mindset of economic actors in seeing money and profits. Financial literacy is an interesting issue in both developed and developing countries and has led to rapid changes in the financial industry. Financial literacy is the ability for someone to read, analyze, manage and communicate economic conditions that affect their welfare. An understanding of basic financial concepts is good, so when making decisions about finance do not experience problems in the future to be able to show economic behaviour healthy to determine the priority needs are not just desires.

Based on figure 1 shows the low level of community inclusion, even the level of ownership of financial services accounts of the younger generation of Indonesia is still lagging compared to Singapore, Malaysia and Thailand. According to OJK (2015), 
literacy level new student finance around $28 \%$ with a financial inclusion rate of $44 \%$. Yet according to Bank Indonesia (2016), inclusive finance can produce various advantages that can be used by the public, regulators, government, and the private sector viz among others flattering economic response strengthening financial policy protection, reducing shadow banking, preparing financial market increasing, providing the current market potential for banks, supporting increasing Human Development Index, provide confidently to local and national economic growth that is sustainable.

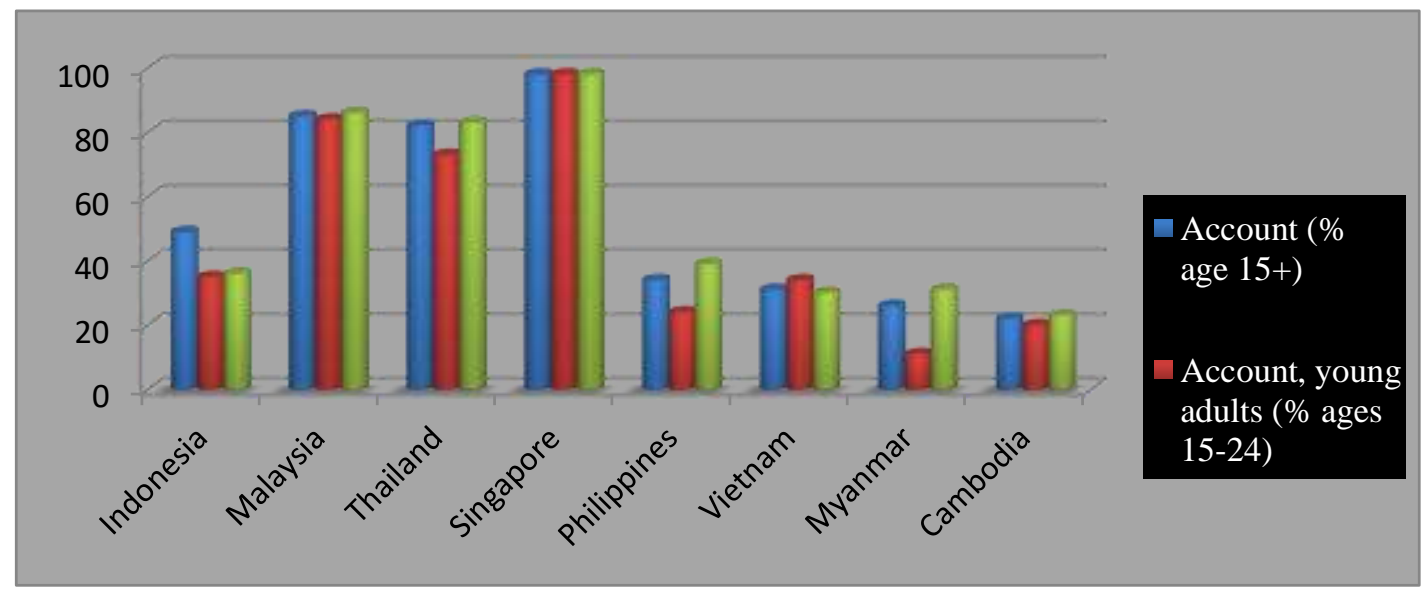

Figure 3.0: Percentage of population that has a bank account in ASEAN in 2017 (Global Financial Inclusion Database (2017)

Higher education is a means to improve the quality of Indonesian Human Resources for the future. For this idea, further severe steps are needed for the Ministry of Research, Technology and Education to be able to increase the Gross Enrollment Rate (GER) in tertiary institutions which are still low when compared to South Korea which reaches 92\%. According to BPS data, APKs at the tertiary level in Indonesia is just $27.98 \%$. The means that the fulfilment of education in high schools has not transferred one-third of the population with active age (19-23 years). When observed based on gender relations, the gross participation of women at the higher education level has reached $30.05 \%$, beating male students who only enter $26 \%$. The APK for women at the tertiary level preceding men has taken place since 2012. The Gross Enrollment Rate (APK) at the tertiary level is indeed far from the target set by the government at $35 \%$ in 2015. It will be throughout $60-70 \%$ in 2045. Although it is however low, the Higher Education Gross Enrollment Rate (APK) proceeds to rise every year, as in 2013 to $23.06 \%$ from the previous year $18.85 \%$ due to the extension of student quotas. As the accelerated development of information technology, it required that campuses could be distance lecture programs to improve the Gross Enrollment Rate (APK) at the college level.

\section{LITERATURE REVIEW}

Financial literacy according to the Indonesian Financial Literacy National Strategy handbook, what is expected by financial literacy is a range of rules or activities to develop the knowledge, determination and abilities of consumers and the larger community so that they can maintain investments more desirable. Based on this understanding, it can conclude that consumers of financial products and services as well 
as the public. It hoped that it would not only know and understand commercial service institutions and financial products and services but also can change or improve people's behaviour in business management so that they can improve their welfare. The success of the development is marked by the creation of a system of financial stability and benefit all levels of society. In this case, financial institutions play an important role through their intermediary functions to encourage economic growth, income distribution, poverty alleviation and financial system stability achievement. It's just that the financial industry that is increasing not necessarily accompanied by access to adequate finance. Even though access to financial services is an essential requirement for the involvement of society at large in the economic system. The banking sector plays a significant role in economic development in Indonesia, namely, to become the driving force for inclusive financial activities. Indonesian banks have a share of commercial activities by up to $80 \%$. However, involvement in inclusive finance is not only related to the tasks of Bank Indonesia, but also the Government in efforts to provide financial services to the broader community.

According to (Lestari, 2015)survey results from the Authority Financial Services in 2016, meaning that the level of literacy and Islamic financial inclusion of the Indonesian people is still low, it is imperative to have a policy of every financial services business actor to improve the index of Islamic financial literacy and inclusion so that Islamic financial products and services frequently identified and used by the society. Specific strategies such as education and outreach activities are still a duty for the Islamic financial services industry so that the public can increase their knowledge of Islamic finance. The Financial Services Authority seeks to improve financial literacy through the blueprint National Financial Inclusive Strategy (SNLKI) program launched in 2013. This strategy aims to increase the high financial literacy index (well literate) in the community. The targets of the SNLKI strategy are housewives, MSMEs, students, students, professions, employees, and retirees. However, along with the development of the concept of financial literacy in various countries, the idea of financial literacy in Indonesia made improvements by publishing the National Literacy Strategy Financial Indonesia (Revisit 2017) by the Financial Services Authority in November 2017. Besides, the results of the 2016 OJK survey on the Indonesian people's financial literacy index that have not yet reached the target, are another consideration in revising SNLKI.

Rajendran (2013) states that achieving financial inclusion not only helps development but also to make social inclusion. Financial inclusion and inclusive economic growth have become the priority list of governments in all developing countries. In other studies compiled by (Rajendran, 1995), (Prescott, 1992), (BD Smith, 1997), (Levite, 1993), (Zervos, 1998)can show that growing bank functions can accelerate the process of resource allocation and growth. Furthermore, Hans and Deepika (2011) assert that the equitable distribution of resources can create for all segments of society with financial inclusion. Hence, Dev (2010) explains that financial inclusion can lead to more prominent efficiency from the financial intermediation process.

On other research, various countries in the world have carried out literacy movements finance successfully. They are of the view that Literacy Finance is a strategic program that is as important as other national programs. Financial literacy is one of the priority programs in many countries, such as Canada, Australia, India, USA, United Kingdom. The financial literacy movement is a long-term national program whose implementation involves various parties. Sharia, financial literacy development 
program, is a strategic effort to support the government (OJK) to realize a federal program to build and improve financial literacy. The purpose of the Islamic financial literacy development program is to expand and increase knowledge, understanding and community participation in the use of Islamic financial products and services. Islamic financial literacy expected to be able to increase public awareness and change people's behaviour in managing finances better, competent and smart in choosing halal and profitable investments, able to prevent people from following fraudulent investments. Financial literacy improvement in the long term aims to enhance the literacy of someone who was earlier limited literate. This goal also certainly applies to the development of Islamic financial literacy. Hence, the purpose of sharia financial literacy is that consumers and the wider community can determine sharia financial products and services that fit their needs. Islamic financial literacy reflects one's cognitive knowledge and abilities in finance. The strength of financial literacy can interpret as the ability to use business knowledge possessed to make decisions and describe the ability to recognize and apply concepts that are relevant to finance.

However, (Huston, 2010)states that factors such as habits, cognitive, economic, family, peers, community, and institutions can have an impact on financial habits. Someone is said to be financially literate when having knowledge and the ability to apply that knowledge. Meanwhile, according to Monticone (2010), explaining the factors that influence financial literacy consists of socio-demographic, cognitive skills, family background, wealth, and time preference. Whereas (R P Volpe, 1998)mention several dimensions of financial literacy, namely general knowledge of finance, savings and loans, insurance, and investment. Furthermore, on the other hand, the potential and growth of the enormous Islamic financial industry require human resources who have competence in the field of Islamic financial sector. Based on this, then several universities established majors or Islamic banking study programs spread in various regions of the archipelago. Through education in higher education, students gain knowledge about the Islamic finance industry, especially Islamic banking. By knowing, you should have understanding, belief and skills in managing sharia finance.

Knowledge obtained by someone certainly will bring different impact on understanding. If a person knows a lot about sharia financial institutions, his intelligence will ultimately shape decisions in choosing Islamic financial products and services. If literacy occurs well, then Islamic financial inclusion is also good. Before someone wants the products and services of Islamic financial institutions, one must first know about the management of Islamic finance.

Apart from that, there are also internal factors such as demographics describing the characteristics of a population. Within these demographic variables, different subcultures will know. At present, demographics are an essential part of consumer behaviour because they are easily accessible and relatively cheaper information to identify market segmentation (Adi, 2017). Gender is what influences financial literacy. Gender is a concept about differences between men and women, including their respective levels of financial literacy (Sharpe, 2009)

But the results of Krishna's research, find different results, namely that women understand better financial literacy compared to men. (Bhusan \& Y, 2013), research by (Othman, M, L , M, \& K, 2008)(Chen \& R, 1998)states that men have higher financial knowledge than women. (Hafizah \& Siti, 2015)also found that the level of sharia financial literacy of men is more leading than women. 


\section{METHOD}

The method that I use in this research is to use a quantitative approach that uses SmartPLS 3. The secondary data that I got was from the Central Statistics Agency (BPS) and the Financial Services Authority (OJK). Data analysis techniques in this study carried out with a model SEM (Structural Equation Modeling). This study uses the SEM model because this study aims to look at the relationship between variables where the variables in this study can be measured directly, but require indicators as a measurement tool.

\section{RESULTS AND DISCUSSION}

This type of research is analytical research in which the researcher explains the causality relationship within variables with hypothesis testing to answer the research questions and objectives. To collect the required data, the authors conducted secondary data research from the Central Statistics Agency (BPS) and the Financial Services Authority (OJK) level. The unit of analysis of this study were students at universities in Indonesia based on secondary data from the Central Statistics Agency.

There are three variables in this study, namely financial literacy, financial inclusion and gross enrollment ratio (GER). Financial literacy consists of some knowledge and abilities related to finance owned by individuals to be able to manage or use a certain amount of money to improve their standard of living. Financial inclusion sees and refers to a person's situation where he can access various financial institutions, products and services as needed and provide benefits for future welfare improvement. The Gross Enrollment Rate (GER) is a condition of the number of students who enter the university both public and private in a certain period.

The analytical tool used is PLS (Partial Least Square), where the processing uses SmartPLS 3.0 software. PLS has two model specifications, namely the inner model and the outer model. The internal model describes the relationship between latent variables based on substantive theory. The hidden model evaluated using Rsquare for the dependent construct, the Stone-Geisser Q-square test for predictive relevance and t-test as well as the significance of the structural path parameter coefficients. The inner model is used to test the research hypotheses where the t-statistic value> 1,960 shows that the influence between variables is significant.

Table 1. Kriteria Inner Model

\begin{tabular}{ll}
\hline \multicolumn{1}{c}{ Evaluation } & \multicolumn{1}{c}{ Criteria } \\
\hline $\begin{array}{l}\text { Between endogenous latent } \\
\text { variables }\end{array}$ & $\mathrm{R}^{2}$ good $(0.67)$ \\
& $\mathrm{R}^{2}$ moderate $(0.33)$ \\
& $\mathrm{R}^{2}$ weak $(0.19)$ \\
Effect size & The greater the $\mathrm{F}^{2}$ the greater the effect \\
Relevansi prediksi & $\mathrm{Q}^{2}$ is getting closer to 1, then the model can predict data \\
\hline
\end{tabular}

For the measurement model or outer model is evaluated by using convergent validity which measures the reflective model of indicators assessed based on the correlation between item scores or component scores with construct scores. Then 
discriminant efficacy of the measurement model with reflective signs is evaluated based on cross-loading measurements with constructs or using other methods by comparing the square root of Average Variance Extracted (AVE) values. Furthermore, composite reliability can measure through two types of measures, namely internal consistency and Cronbach's Alpha.

Table 2: Criteria Outer model

\begin{tabular}{ll}
\hline \multicolumn{1}{c}{ Evaluation } & \multicolumn{1}{c}{ Criteria } \\
\hline $\begin{array}{l}\text { Convergent validity, Loading factor, Average Variance Extracted } \\
\text { (AVE) }\end{array}$ & Outer loading $\geq$ \\
& 0.50 \\
Discriminant validity, AVE Root> Correlation between variables & $\geq 0.50$ \\
Reliability Test, Composite reliability & $\geq 0.50$ \\
\hline
\end{tabular}

Hypothesis testing using loading factors by looking at the value of the critical ratio $(\mathrm{CR})$ ( $\mathrm{t}$ arithmetic) with $\mathrm{t}$ table with the provisions, that if $\mathrm{CR}>\mathrm{t}$ table with $\mathrm{p} \leq$ 0.05 means significant and if $\mathrm{CR}<\mathrm{t}$ table with $\mathrm{p} \geq 0.05$ means not significant. This test can be done with t-statistics when $t$ value $>t$ table $( \pm 1.98$ in the error rate of $5 \%$ or \pm 1,658 in the error rate of $10 \%$ ). If the test results of the model are significant, it means that there is an influence between latent variables.

Testing in PLS statistically on each hypothesized relationship will be through simulation using the bootstrap method of the sample. The bootstrap method aims to minimize the problem of research data that is not normal. Hypothesis testing is done by comparing t-tables and t-statistics. T-table can be obtained from 100 respondents with a significance value $<0.05$ and t-table value $>1.960$. The results of testing through bootstrapping are as follows:

Table 3. Research Hypothesis Testing Results

\begin{tabular}{|c|c|c|c|c|c|c|c|}
\hline \multicolumn{8}{|c|}{ Path Coefficients } \\
\hline Hipotesis & Variabel & & $\begin{array}{l}\text { Original } \\
\text { Sample } \\
\text { (O) }\end{array}$ & $\begin{array}{l}\text { Sample } \\
\text { Mean } \\
\text { (M) }\end{array}$ & $\begin{array}{c}\text { Standard } \\
\text { Deviation } \\
\text { (STDEV) }\end{array}$ & $\begin{array}{c}\text { T Statistics } \\
(|\mathrm{O} / \mathrm{STDEV}|)\end{array}$ & P Values \\
\hline H1 & $\begin{array}{l}\text { Gross } \\
\text { Enrollment } \\
\text { Ratio } \\
\text { Financial } \\
\text { Literacy }\end{array}$ & $->$ & 0.198 & 0.228 & 0.146 & 1.363 & 0.560 \\
\hline H2 & $\begin{array}{l}\text { Gross } \\
\text { Enrollment } \\
\text { Ratio } \\
\text { Financial } \\
\text { Inclusion }\end{array}$ & $->$ & 0.098 & 0.086 & 0.169 & 0.583 & 0.173 \\
\hline
\end{tabular}

The first hypothesis, which examines the relationship between GER and financial literacy, shows the original sample value of 0.198 and t-statistics 1.363 . The measurement results show that the t-statistic <t table (significance level of $5 \%=1.96$ ), 
the first hypothesis in this study rejected. From the results of these data, it can be interpreted that the sample data of the independent latent variable (GER) did not succeed in proving the relationship with the latent variable dependent (financial literacy), or in other words, the Gross Enrollment Ratio did not significantly influence Financial Literacy with the direction of a positive relationship.

The second hypothesis, which examined the relationship between GER and financial inclusion, showed an original sample value of 0.098 and a t-statistic of 0.583 . The measurement results show that the t-statistic <t table (significance level of $5 \%=$ 1.96), the first hypothesis in this study rejected. From the results of these data, it can be interpreted that the sample data of the independent latent variable (GER) did not succeed in proving the relationship with the latent dependent variable (financial inclusion), or in other words, the Gross Enrollment Ratio did not significantly influence Financial inclusion with a positive direction.

\section{CONCLUSION}

From the discussion above, it can conclude that the level of Gross Enrollment Ratio of the University is not significant to the literacy and inclusion of Islamic finance in Indonesia. But several other variables can affect the level of literacy and Islamic financial inclusion apart from the Gross Enrollment Ratio of the University. This research still has many limitations, so there is still plenty of room to develop further analysis in-depth. This research focuses on the Gross Enrollment Ratio on literacy and Islamic financial inclusion in Indonesia. Besides, several other factors make the Gross Enrollment Ratio of shariah literacy and financial inclusion in Indonesia still low. One of which is the fact that students in Indonesia are not yet interested in knowing more about sharia finance in addition to factors from the competition with conventional system finance.

\section{REFERENCES}

Almanshur, Fauzan, \& Djunaidi, G. (2012). Metodologi Penelitian Kualitatif. Yogyakarta: Ar Ruzz Media.

BD Smith, J. G. (1997). Financial Markets in Development and The Development of Financial Markets. Journal of Economuc Dynamics and Control, 145-181.

Bhusan, P., \& Y, M. (2013). Financial Literacy its Determinants. International Journal of Engineering Business and Entreorise Applications (IJEBEA), 155-160.

Chen, \& R, R. V. (1998). Analysis of Financial Literacy Among College Studnets. Financial Sercvices Review, 107-128.

Darsono. (2016). Perjalanan Perbankan Syariah di Indonesia. Jakarta: Bank Indonesia.

Dwitya, A. (2016). Pengaruh Literasi Keuangan Terhadap Kinerja dan Keberlangsungan UMKM di Jawa Tengah. Jurnal Siasat Bisnis, 1-13.

Fitriyanti, \& Mustjari. (2010). Hukum Perbankan Syariah dan Takaful. Yogyakarta: Lab Hukum FH UMY.

Hafizah, \& Siti, A. R. (2015). Psychosocial Factors and Gender Infleuncing the Level of Islamic Financial Literacy. Journal Universiti Utara Malaysia, 160-175.

Huston, S. J. (2010). Measuring Financial Literacy. The Journal of Consumer Affairs, 296-316. 
INFE, O. (2012). High-Level Principles on National Strategies for Financial Education. Paris: OECD.

John, C. (2010). Research Design Pendekatan Kualitatif, Kuantitatif, dan Mixed. Yogyakarta: Pustaka Pelajar.

Karim, A. (2010). Bank Islam : Analisis Fiqh dan Keuangan. Jakarta: Raja Grafindo.

Keuangan, O. J. (2014). Implementasi Strategi Nasional Literasi Keuangan Indonesia. Jakarta: OJK.

Krishna, Rofaida, \& Sari. (2010). Analisis Tingkat Literasi Keuangan di Kalangan Mahasiswa dan Faktor-Faktor yang mempengaruhinya (Survey pada Mahasiswa Universitas Pendidikan Indonesia). In Proceedings of The 4th International Conference on Teacher Eduction (pp. 552-560). Bandung: Other.

Kumar, \& Nitin. (2013). Financial Inclusion and Its Determinants : Evidence from India. Journal of Financial Economy Policy, 4-19.

Lestari, S. (2015). Literasi Keuangan Serta Penggunaan Produk dan Jasa Lembaga Keuangan. Jurnal Fokus Bisnis, 14-24.

Levite, K. (1993). What we Have Learned About Policy and Growth from CrossCountry Regression? America Economic Review, 426-430.

Lusardi, A., \& O, M. (2014). The Economic Importance of Financial Literacy: Theory and Evidence. . Journal of Economic Literature, 1-8.

Margaretha, Farah, \& Reza, P. (2015). Tingkat Literasi Keuangan pada Mahasiswa S1 Fakultas Ekonomi. Jurnal Manajemen Keuangan, 76-85.

Mendari, Sri, A., \& Suramaya. (2013). Tingkat Literasi Keuangan di Kalamangan Mahasiswa STIE Musi. . Jurnal Economia, 130-140.

Njoroge, C. W., \& J, M. G. (2013). The Effect of Entrepreneurial Education and Training on Development of Small and Medium Size Enterprises in Githunguri District KENYA. International Journal of Education and Research, 1-22.

Nunoo, J., \& F, K. A. (2012). Sustaining Small and Medium Enterprises through Financial Service Utilization: Does Fnancial Literacy Matter?. . International Journal of Economics and Financial, 31-40.

OECD. (2011). Measuring Financial Literacy : Core Questionnaire in Measuring Financial Literacy : Questionnaire and Guidance Notes for Conducting an Internationally Comparable Survey of Financial Literacy. Paris: OECD.

OECD. (2013). The Role of Financial Education in Financial Inclusion : OECD / INFE Evidence, Policies and Illustrative Case Studies. Moscow : G20 Communiqué Meeting of Finance Ministers and Central Bank Governors. Paris: OECD.

OECD. (2013). The Role of Financial Education in Financial Inclusion : OECD / INFE Evidence, Policies and Illustrative Case Studies. Moscow : G20 Communiqué Meeting of Finance Ministers and Central Bank Governors. Paris: OECD.

OJK. (2013). Tingkat Literasi Keuangan Konsumen berdasarkan Survei 2013. Jakarta: OJK.

Others. (2017). Global Financial Inclusion Database. London: Other.

Othman, S., M, A. M., L , P., M, M., \& K, T. H. (2008). Financial Behavior and Problems Among College Students in Malaysia. Research and Education Implication Consumer Interest Annual, 166-170.

Poopy, A. S., Kusdi, R., \& Mohammad , I. (2019). Pengaruh Literasi Keuangan dan Inklusi Keuangan Terhadap Kinerja Usaha Kecil di Kalimantan Timur. Jurnal Economia, 34-45. 
Prescott, B. (1992). A Sensitivity Analysis of Cross-Country Growth Regression. New York: America Economic Review.

R P Volpe, H. C. (1998). An Analysis of Personal Financial Literacy Among College Studens. Financial Services Review, 107-128.

Rajendran. (1995). Stock Market Development and Long0Run Growth. World Bank Economics Review, 942-963.

Sharpe, R. (2009). Effect of Personal Knowledge on Collage Student's Credit Car Behavior. Journal of Financial Counseling an Planning, 25-43.

Zervos, L. (1998). Stock Market, Banks and Economic Growth. New York: America Economic Review. 